\title{
Brain-derived neurotrophic factor (BDNF) affects somatotrophic axis activity in sheep
}

\author{
B.J. Przybył, A. Wójcik-Gładysz', A. Gajewska and M. Szlis \\ The Kielanowski Institute of Animal Physiology and Nutrition, Polish Academy of Sciences \\ Instytucka 3, 05-110 Jabłonna, Poland
}

KEY WORDS: BDNF, GHRH, growth hormone, hypothalamus, pituitary, sheep, somatostatin

Received: 27 July 2021

Revised: 19 October 2021

Accepted: 26 October 2021

${ }^{1}$ Corresponding author: e-mail: a.wojcik@ifzz.pl

\begin{abstract}
Brain-derived neurotrophic factor (BDNF) is a growth protein factor belonging to the neurotrophin peptide family that is involved in the regulation of several activities of the central nervous system. However, its effects on the activity of the somatotrophic axis in ruminants have not yet been determined. The present study aimed to verify the research hypothesis, which assumed that BDNF can modulate key hormones of the somatotrophic axis in sheep. The experiment involved sexually mature Polish Merino sheep $(n=24)$. The animals were divided into three groups, and the following intracerebroventricular infusions were performed: control group received Ringer-Locke solution $(480 \mu \mathrm{l} /$ day), BDNF10 - BDNF at a dose of $10 \mu \mathrm{g} / 480 \mu \mathrm{l} /$ day and BDNF60 BDNF at a dose of $60 \mu \mathrm{g} / 480 \mu \mathrm{l} /$ day. Blood samples were collected on days 0 and 3 of infusions. After the experiment, the animals were slaughtered and selected structures of the hypothalamus, pituitaries and plasma samples were stored for Real-Time reverse transcription-polymerase chain reaction (Real-Time RT-PCR) and radioimmunoassay analysis. It was revealed that central BDNF administration induced a dose-dependent increase in growth hormone relasing hormone $(G H R H)$ mRNA expression in the mediobasal hypothalamus of sheep. Moreover, central BDNF administration increased growth hormone $(G H)$ mRNA expression in the pituitary and the $\mathrm{GH}$ pulse amplitude, which, consequently, increased the mean $\mathrm{GH}$ concentration in the blood plasma. These observations suggest the up-regulation of the somatotrophic axis activity in female sheep after BDNF infusion. So, it can be stated that BDNF is involved in the modulation of key hormones co-creating the somatotrophic axis in mature sheep.
\end{abstract}

\section{Introduction}

Brain-derived neurotrophic factor (BDNF), a growth protein factor belonging to the neurotrophin peptide family, participates in mechanisms that promote differentiation and survival of developing neurons. Moreover, BDNF is involved in processes related to neuronal neuroplasticity and neuroprotective mechanisms, such as the stimulation of nerve growth and the formation of synaptic connections between nerve cells (Peiris et al., 2004).
Brain-derived neurotrophic factor mRNA is located in several areas of the brain; for example, in the neocortex, hippocampus, medulla oblongata and hypothalamus. In the mediobasal hypothalamus (MBH), BDNF immunoreactive material has been identified in the paraventricular (PVN), arcuate (ARC), ventromedial (VMN) or dorsomedial (DMN) nuclei, as well as in the median eminence (ME) (Unger et al., 2007; Cordeira et al., 2010). The presence of tyrosine kinase receptor isoform $\mathrm{B}$ (TrkB), which is a specific receptor for BDNF, 
has also been demonstrated in the above-mentioned structures (Timmusk et al., 1993; Patapoutian and Reichardt, 2001).

Precise information about the central mechanisms that underlie the molecular interactions between BDNF and key hormones of the somatotrophic axis, especially in sexually mature mammals, is still insufficient. Current studies focusing on the role of BDNF predominantly involve embryos or newborn rodents and can only indicate its action during the early development of the brain. Studies conducted on rat embryonic cerebral cortical cell cultures have demonstrated that BDNF can modulate somatostatin $(S R I F)$ mRNA expression in nerve cells. Other studies conducted on rat foetal hypothalamic cell cultures have shown that BDNF has a dose-dependent effect on the release of SRIF from hypothalamic neurons (Marmigère et al., 2001). In in vivo studies, it was demonstrated that the infusion of BDNF in neonatal rats (1-2 days after birth) increases SRIF mRNA concentrations in the anterior neocortex (Nawa et al., 1994). It is important to note that studies conducted on juvenile organisms do not always reflect the processes and regulations that occur in mature individuals.

The location of BDNF mRNA and proteins, as well as the BDNF receptor, in the above-mentioned specific regions of the central nervous system (CNS), suggests that BDNF is involved in the central regulation of appetite modulation processes. The results of our earlier study revealed that BDNF can affect the activity of the main neuropeptides co-creating the appetite regulation centre localised in the ARC nucleus in the hypothalamus of sheep. Neuropeptide $\mathrm{Y}(N P Y)$, agouti-related peptide $(A g R P)$ and proopiomelanocortin $(P O M C)$ mRNA expression increased after BDNF intracerebroventricular (ICV) infusion (Przybył et al., 2020). On the other hand, our previous research demonstrated that several factors involved in appetite regulation processes, such as NPY, ghrelin and obestatin, can change the somatotrophic axis hormones secretory activity in sheep (WójcikGładysz et al., 2014, 2018, 2019; Wójcik-Gładysz and Szlis, 2016; Szlis et al., 2018). It is well-known that the activity of the somatotrophic axis in the CNS may also be modulated by several factors, such as drugs, antibiotics and neurotrophins (Timmusk et al., 1993; Patapoutian and Reichardt, 2001; Kennedy, 2012). Based on this information, BDNF may also participate in the complex neurohormonal network that modulates the somatotrophic axis activity.

The results of our earlier study revealed that in female sheep the main activities of somatostatin- containing neurons in the periventricular nucleus (PEV) are known for their involvement in the control of growth hormone $(\mathrm{GH})$ secretion (Polkowska et al., 2008; Tillet et al., 2010). Additionally, this discrete (specific) population of somatostatin neurons is the most sensitive to the action of the orexigenic and anorexigenic peptides (hormones) like leptin, ghrelin or obestatin (Polkowska et al., 2010; Wójcik-Gładysz et al., 2010, 2018).

So, it can be assumed that in sheep, BDNF may be involved in the modulation of somatotrophic axis activity, as another regulating peptide engaged in the complex neurohormonal network modulating this axis function. The aim of the study was to verify the hypothesis whether BDNF acts as a hormonal signal affecting the activity of the main components involved in the growth processes regulation in, i.a., hypothalamic growth hormone releasing hormone (GHRH) neurons, hypothalamic SRIF neurons and pituitary somatotrophic cells.

\section{Material and methods}

\section{Animals and experimental design}

All procedures adhered to the Code of Ethics of the World Medical Association (Declaration of Helsinki), as well as the EU Directive 2010/63/EU for animal experiments, and were approved by the Local Ethics Committee affiliated to Warsaw University of Life Sciences - SGGW (consent no. 22/2015 of 21 May 2015) according to the Polish Law for the Animal Care and Use (21 January 2005) and the Polish Law for Animal Protection (16 September 2011).

Twenty-four female Polish Merino sheep $(42$-week old, average weight $=38.6 \pm 3.5 \mathrm{~kg})$ were used in the study. The animals were housed indoors under natural lighting conditions $\left(52^{\circ} \mathrm{N}, 21^{\circ} \mathrm{E}\right)$ and fed a standard diet containing hay (approximately $\sim 2 \mathrm{~kg}$ per day) with commercially available concentrates (approximately $\sim 0.4 \mathrm{~kg}$ per day). Sheep were fed twice a day (around 8:00 and 14:00) according to Polish recommendations for ruminants (Strzetelski et al., 2014). Water and salt licks were provided for each sheep ad libitum. The reproductive status of each animal was assessed every week (from the beginning of August) by evaluating plasma progesterone concentrations and verified by post-mortem ovary examination (data not shown).

Stainless steel cannulas were implanted directly into the third ventricle (IIIv) using a specialised stereotaxic apparatus for sheep and based on the methodology described by Traczyk and Przekop (1963). 
The animals were anaesthetised with atropinum sulphuricum (0.44 mg/kg; Polfa, Warsaw, Poland), ketamine (400 mg per sheep; Vetoquinol Biowet, Gorzów Wielkopolski, Poland), and dexmedetomidine $\left(0.05 \mathrm{mg} / \mathrm{kg}\right.$, Dexdomitor ${ }^{\circledR}$; Orion Pharma, Turku, Finland) during the procedure. Permanent stainless-steel guide cannulas $(0.8 \mathrm{~mm})$ were inserted into the IIIv (coordinate of guide cannulas implantation: anteroposterior position $-31.0 \mathrm{~mm}$, horizontal position $-0.5 \mathrm{~mm}$, mid-sagittal position $-0.1 \mathrm{~mm}$ ) according to the atlas of sheep brain by Welento et al. (1969). The position of the guide cannula was verified by an X-ray examination, efflux of the cerebrospinal fluid upon removal of the guide tube stiletto and post-mortem brain inspection. After surgery, penicillin-streptomycin $(0.1 \mathrm{ml} / \mathrm{kg}$; ScanVet, Gniezno, Poland) and tolfenamic acid $\left(0.05 \mathrm{ml} / \mathrm{kg}\right.$, Tolfine ${ }^{\circledR}$; Vetoquinol Biowet, Gorzów Wielkopolski, Poland) were administered by subcutaneous injection over four consecutive days, followed by a five-week recovery period.

In all experimental animals, oestrus synchronisation was performed 21 days before the ICV infusion using Chronogest CR sponges (MSD Animal Health, Walton, UK). One polyester polyurethane sponge containing $20 \mathrm{mg}$ of flugestone acetate (a synthetic analogue of progesterone) was administered intravaginally and independently of body weight or the individual day of the oestrus cycle. After 14 days, the sponge was gently removed, and the serum gonadotropin of a pregnant mare was injected intramuscularly (PMSG; 500 IU per animal; Folligon, Intervet Int., Boxmeer, Netherlands) to facilitate ovulation. Oestrus occurred within 48-72 $\mathrm{h}$ after PMSG administration (Krawczyńska et al., 2019; Rekešiutè et al., 2020). The appearance of oestrus was additionally detected using a vasectomised ram. Animals entered the experiment on days 4-5 after ovulation when a decrease in the oestrogen concentration in the peripheral blood of the sheep was observed (Kennedy, 2012).

The experiments were conducted from the end of October to the first week of December. The animals were randomly divided into three experimental groups: control group receiving an ICV infusion of Ringer-Locke solution (artificial cerebrospinal fluid; $480 \mu 1$ per day; $\mathrm{n}=8$ ), BDNF 10 group receiving an ICV infusion of BDNF (Santa Cruz Biotechnology, Inc., Dallas, TX, USA) at a dose of $10 \mu \mathrm{g}$ per day $(\mathrm{n}=8)$ and BDNF60 group receiving BDNF at a dose of $60 \mu \mathrm{g}$ per day $(\mathrm{n}=8)$; BDNF in both groups was diluted in $480 \mu 1$ of Ringer-Locke solution; in all three groups an infusion rate was $120 \mu \mathrm{l} / \mathrm{h}$. The doses of BDNF used in this experiment were chosen based on information from the literature (Barde et al., 1982; Givalois et al., 2006; Cordeira et al., 2010) as well as our previous experience in neuroendocrine research (Przybył et al., 2020).

During the experiment, cannulas were introduced through the guide cannulas and locked into position $1 \mathrm{~h}$ before the infusion, with their tips placed approximately $2.0-2.5 \mathrm{~mm}$ above the base of the brain; when the tips of the cannulas were in the IIIv, the cerebrospinal fluid flowed into the infused cannulas. All sheep received four $50-\mathrm{min}$ ICV infusions at 30-min intervals, which were performed from 08:40 to 13:30 on each of three consecutive days using a BAS Bee MD_1020 904 microinjection pump (Bioanalytica Systems Inc., West Lafayette, IN, USA). To prevent a rapid increase in pressure through the Ringer-Locke and BDNF infusions into the IIIv, the flow rate of the microinjection pump was set to $2 \mu \mathrm{l} / \mathrm{min}$. The infusion pattern was designed to mimic the pulsatile release of neurohormones synthesised in the CNS in a sheep model (Wójcik-Gładysz et al., 2016, 2018; Herman et al., 2017; Szlis et al., 2020; Przybył et al., 2021). Blood samples were collected a day before (day 0 ) and on the third day of infusion (day 3) from 08:00 to 13.50 at 10-min intervals. Immediately after the last blood sample was collected, the animals were weighed, anaesthetised intravenously using dexmedetomidine $(0.05 \mathrm{ml} / \mathrm{kg}$, Dexdomitor $^{\circledR}$; Orion Pharma, Turku, Finland) and pentobarbital $\left(80 \mathrm{ng} / \mathrm{kg}\right.$, Morbital ${ }^{\circledR}$; Vetoquinol Biowet, Gorzów Wielkopolski, Poland), and decapitated. Isolation of selected hypothalamic structures (area and depth of the cut) was performed according to the stereotaxic coordinates defining the individual hypothalamic nuclei described in the anatomic atlas of the sheep hypothalamus (Welento et al., 1969). The brain regions encompassing the preoptic area (POA) and hypothalamus were sectioned sagittally and dissected from both sides into the following parts: anterior hypothalamus area (AHA; cut coordinate: anteroposterior 34.75-37.70; sagittal 0.18-2.32; horizontal $+3.27-+8.34$ ) and MBH (cut coordinate: anteroposterior 30.82-33.62; sagittal $0.00-2.88$; horizontal $0.54-+4.53)$. The depths of the cuts were $2-2.5 \mathrm{~mm}$ for $\mathrm{MBH}$ and 2.5-3 mm for AHA (Wójcik-Gładysz et al., 2018). The pituitary gland was removed from the skull, weighted and divided into anterior (glandular) and posterior (nerve) parts. All tissues were immediately frozen in liquid nitrogen and stored at $-80{ }^{\circ} \mathrm{C}$ until Real-Time reverse transcription-polymerase chain reaction (Real-Time RT-PCR) analysis. 


\section{Real-Time RT-PCR}

Total mRNA from the AHA, MBH and pituitary was extracted using a NucleoSpin RNA/Protein kit (Macherey-Nagel GmbH \& Co., Düren, Germany) according to the manufacturer's instructions. The yield of isolated RNA was estimated spectrophotometrically (NanoDrop Technologies Inc., Wilmington, DE, USA), and its integrity was evaluated electrophoretically by separation on a $1.5 \%$ agarose gel containing ethidium bromide. For complementary DNA (cDNA) synthesis, $1500 \mathrm{ng} / \mathrm{ml}$ mRNA from the selected hypothalamic regions in a total volume of $20 \mu \mathrm{l}$ was retro-transcribed using a TranScriba Kit (A\&A Biotechnology, Gdynia, Poland) according to the manufacturer's protocol. Specific primers for the sheep species (Ovis aries) that determine the expression of housekeeping gene and genes of interest were designed using the Primer 3 software (The Whitehead Institute, Cambridge, MA, USA) and synthesised by Genomed (Warsaw, Poland). The primer sequences are listed in Table 1. protocol: one cycle at $95{ }^{\circ} \mathrm{C}$ for $15 \mathrm{~min}$ (enzyme activation), followed by 35 cycles at $94{ }^{\circ} \mathrm{C}$ for $5 \mathrm{~s}$ (denaturation), $59^{\circ} \mathrm{C}$ for $20 \mathrm{~s}$ (annealing) and $72^{\circ} \mathrm{C}$ for $15 \mathrm{~s}$ (elongation), followed by one cycle at $72^{\circ} \mathrm{C}$ for $7 \mathrm{~min}$ (product stabilisation). The melting curve was performed over $70-95{ }^{\circ} \mathrm{C}$ at $0.5{ }^{\circ} \mathrm{C}$ intervals. Negative controls without a cDNA template were included for each reaction. Real-Time RT-PCR for each cDNA sample was performed twice in triplicates. The identities of the PCR products were confirmed by direct sequencing (Genomed, Warsaw, Poland).

The relative gene expression was calculated using the comparative quantitation option of the Rotor Gene 6000 software 1.7 (Qiagen GmbH, Hilden, Germany) and determined using the Relative Expression Software Tool (2008) by Pfaffl et al. (2002) based on a PCR efficiency correction algorithm developed by Pfaffl et al. (2004). In this study, glyceraldehyde3-phosphate dehydrogenase $(G A P D H), \quad \beta$-actin $(A C T B)$ and peptidylprolyl isomerase $\mathrm{C}$ (PPIC) genes were used as housekeeping genes. Using the

Table 1. Primer sequences used in the experiment

\begin{tabular}{|c|c|c|c|c|}
\hline Gene & Primer & Sequence $\left(5^{\prime} \rightarrow 3^{\prime}\right)$ & Product size, nt & References \\
\hline \multirow[t]{2}{*}{ GAPDH } & Forward & AGAAGGCTGGGGCTCACT & 134 & Szlis et al. (2020) \\
\hline & Reverse & GGCATTGCTGACAATCTTGA & & \\
\hline \multirow[t]{2}{*}{ ACTB } & Forward & AAGACCTCTACGCCAAACACG & 145 & NM_001009784.3 \\
\hline & Reverse & ACGGAGTACTTGCGCTCAG & & \\
\hline \multirow[t]{2}{*}{ PPIC } & Forward & TGGCACTGGTGGTATAAGCA & 145 & XM_004008676.5 \\
\hline & Reverse & GGGCTTGGTCAAGGTGATAA & & \\
\hline \multirow[t]{2}{*}{ SRIF } & Forward & CTCCATCGTCCTGGCTCTT & 113 & Szlis et al. (2018) \\
\hline & Reverse & ACTTGGCCAGTTCCTGTTTG & & \\
\hline \multirow[t]{2}{*}{ GHRH } & Forward & СCTCTCAGGATTCCACGGTA & 146 & Szlis et al. (2018) \\
\hline & Reverse & CGTACCTTTGCTCCTTGCTC & & \\
\hline \multirow[t]{2}{*}{ GHRHR } & Forward & CTTCTGGTGGCTGGTTCTCG & 173 & NM_001009454.1 \\
\hline & Reverse & GCCCAAAGTTCACCCCAACA & & \\
\hline \multirow[t]{2}{*}{$\mathrm{GH}$} & Forward & CAGGTTGCCTTCTGCTTCTC & 164 & Liu et al. (2019) \\
\hline & Reverse & ACCAGGCTGTTGGTGAAGAC & & \\
\hline \multirow[t]{2}{*}{ SSTR2 } & Forward & GGAGCGGAGTGACAGTAAGC & 178 & XM_004013144.3 \\
\hline & Reverse & GGTCTCCATTGAGGAGGGTC & & \\
\hline \multirow[t]{2}{*}{ SSTR5 } & Forward & GTCATGAGCGTGGATCGCTA & 71 & NM_001009265.1 \\
\hline & Reverse & AGGTGAGGTTGCAGGTGTTC & & \\
\hline
\end{tabular}

Genes encoding: GAPDH - glyceraldehyde-3-phosphate dehydrogenase, ACTB - $\beta$-actin, PPIC - peptidylprolyl isomerase C, SRIF - somatostatin, GHRH - growth hormone releasing hormone, GHRHR - growth hormone releasing hormone receptor, $\mathrm{GH}$ - growth hormone, SSTR2 - somatostatin receptor type 2, SSTR5 - somatostatin receptor type 5

Real-Time RT-PCR was conducted using $5 \times$ FIREPol EvaGreen qPCR Mix Plus (no ROX; Solis BioDyne, Tartu, Estonia) in a total volume of $15 \mu \mathrm{l}$ containing $3 \mu \mathrm{l}$ Master Mix, $9 \mu 1$ RNase free $\mathrm{H}_{2} \mathrm{O}, 2 \times 0.5 \mu \mathrm{l}$ primers $(0.5 \mathrm{mM})$ and a $2-\mu \mathrm{l}$ cDNA template. Amplification was performed using a Rotor Gene 6000 thermocycler (Corbett Research, Mortlake, Australia) according to the following
Best-Keeper software (http://www.gene-quantification.de/bestkeeper.html), GAPDH was chosen as the best endogenous control to normalise gene expression in this study. The results are presented as relative gene expression of the target gene normalised to the housekeeping gene (GAPDH); the relative gene expression for the group of sheep that received only Ringer-Locke solution infusion was set to 1.0. 


\section{Preparation of pituitary homogenates}

For homogenization, the $30 \mathrm{mg}$ of anterior part of pituitary were placed in $1 \mathrm{ml}$ phosphate-buffer (pH 7.0) containing $1.5 \mu \mathrm{l}$ of aprotinin (SigmaAldrich, St. Louis, MO, USA) to protect proteins from degradation. Homogenization was performed using steel balls ( $50 \mathrm{~Hz}, 5 \mathrm{~min}$ ). Next samples were centrifuged ( $3000 \mathrm{rpm}, 3 \mathrm{~min}$ ) and the obtained supernatant was collected and frozen at $-20{ }^{\circ} \mathrm{C}$ for radioimmunoassay analysis.

\section{Radioimmunology of GH}

The concentration of GH in pituitary and plasma was estimated according to the protocol described previously by Wójcik-Gładysz et al. (2018). The GH concentration of the plasma samples was determined using a double-antibody radioimmunoassay (RIA) with anti-ovine GH (rabbit) and anti-rabbit gamma-globulin antisera, as described in detail by Slaba et al. (1994). The reference standard for $\mathrm{GH}$ and anti-ovine $\mathrm{GH}$ antiserum were provided by Dr A.F. Parlow (National Institutes of Health, Bethesda, MD, USA). The assay sensitivity was $0.68 \mathrm{ng} / \mathrm{ml}$, and the intra- and inter-assay coefficients of variability were 5.9 and $10.2 \%$, respectively.

\section{Statistical analysis}

The pulse characteristics were determined using the method described by Goodman and Karsch(1980) and verified using the GraphPad Prism 5 software (GraphPad Software Inc., La Jolla, CA, USA) algorithms for pulse measurement. The analyses were performed individually for each sheep, and the entire sampling period was included. All data are presented as mean \pm standard error of measurement

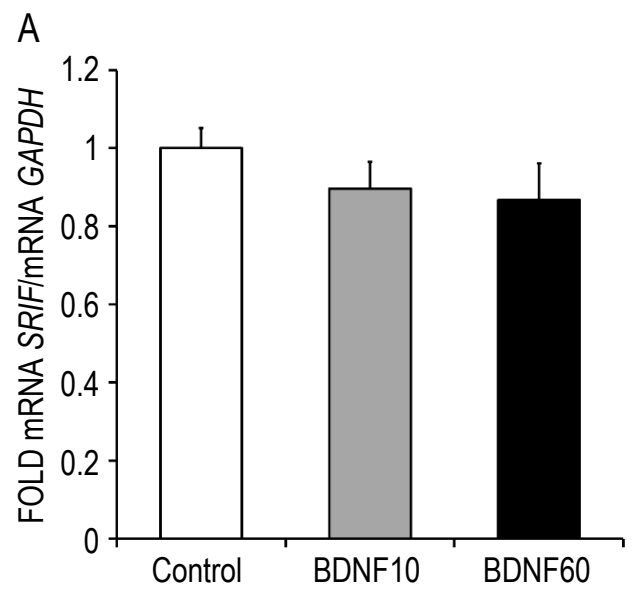

for each group. The normal distribution of the data was tested using the Shapiro-Wilk test.

The statistical data evaluations for gene expression were performed using a one-way analysis of variance (ANOVA).

The mean concentrations of GH for the individual animals were calculated based on the area under the curve (the sum of the trapezoidal areas between the curve and the abscissa). The statistical analysis of the data for the radioimmunoassay was carried out using the nonparametric Kruskal-Wallis test followed by a post-hoc test (Dunn's multiple comparison test). Differences were considered statistically significant at $P \leq 0.05$, with tendencies discussed at $P \geq 0.05$.

\section{Results}

\section{Animals}

The mean weight of the collected pituitary glands was $0.535 \pm 0.11 \mathrm{~g}$ (minimal weight of collected pituitary was $0.414 \mathrm{~g}$; maximal weight of collected pituitary was $0.807 \mathrm{~g}$ ). No differences in pituitary weight were observed across the experimental groups.

\section{Expression of SRIF and GHRH mRNA in the hypothalamus}

Real-Time RT-PCR analyses revealed the presence of SRIF mRNA in the AHA as well as GHRH mRNA in the MBH in all the groups of sheep. At the hypothalamic level, exogenous BDNF affected GHRH mRNA expression in $\mathrm{MBH}$ in a dosedependent manner (Figure 1B). When compared to the GHRH mRNA level in the control group,



Figure 1. Expression of somatostatin (SRIF) mRNA in anterior hypothalamus area (A) and growth hormone releasing hormone (GHRH) mRNA in medio-basal hypothalamus (B). All values are relative to glyceraldehyde-3-phosphate dehydrogenase (GAPDH) mRNA. Data are means \pm standard error of measurement; treatment groups: control group of animals which received Ringer-Locke infusion at dose of $480 \mu \mathrm{l}$ per day $(n=8)$, BDNF10 - group of animals which received brain derived neurotrophic factor (BDNF) infusion at dose $10 \mu \mathrm{g} / 480 \mu \mathrm{l}(\mathrm{n}=8)$, BDNF60 - group of animals which received BDNF infusion at dose $60 \mu \mathrm{g} / 480 \mu \mathrm{l}(\mathrm{n}=8) ;$ different at $P<0.05$ and $P<0.001$, respectively 

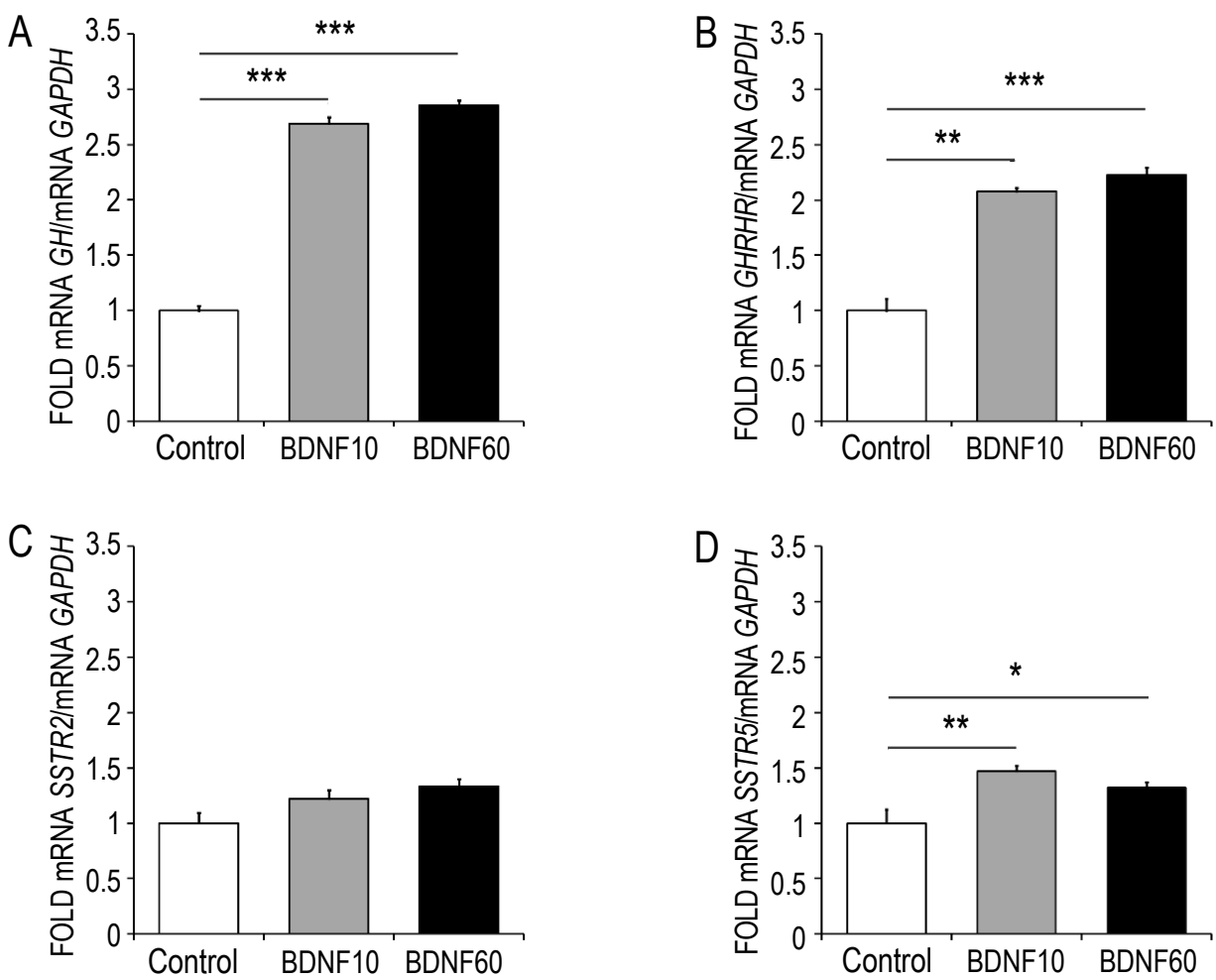

Figure 2. Expression of growth hormone $(G H, A)$, growth hormone releasing hormone receptor $(G H R H R$, B), somatostatin receptor type 2 (SSTR2, C) and somatostatin receptor type 5 (SSTR5, D) mRNA in pituitary. All values are relative to glyceraldehyde-3-phosphate dehydrogenase $(G A P D H)$ mRNA. Data are means \pm standard error of measurement; treatment groups: control group of animals which received RingerLocke infusion at dose of $480 \mu \mathrm{l}$ per day $(n=8), B D N F 10$ - group of animals which received brain-derived neurotrophic factor (BDNF) infusion at dose $10 \mu \mathrm{g} / 480 \mu \mathrm{l}(\mathrm{n}=8), \mathrm{BDNF60}$ - group of animals which received BDNF infusion at dose $60 \mu \mathrm{g} / 480 \mu \mathrm{l}(\mathrm{n}=8) ;{ }^{*},,+,+$ indicate values significantly different at $P<0.05, P<0.01$ and $P<0.001$, respectively

an increase of $2.93 \pm 0.13(P \leq 0.05)$ and $6.99 \pm$ $0.06(P \leq 0.001)$ fold in $G H R H$ transcription occurred in the BDNF10 and BDNF60 groups, respectively. In contrast, BDNF was ineffective in modulating SRIF mRNA expression in the AHA (Figure 1A).

\section{Expression of SSTR2, SSTR5, GHRHR and $G H$ mRNA in the pituitary}

At the pituitary level, BDNF induced an increase in GH (Figure 2A), GHRHR (Figure 2B), and SSTR5 mRNA expression (Figure 2D). In the BDNF10 and BDNF60 groups, the expression of $G H$ mRNA increased by $2.69 \pm 0.06(P \leq 0.001)$ and $2.86 \pm 0.04$ $(P \leq 0.001)$; the expression of GHRHR mRNA increased by $2.08 \pm 0.03(P \leq 0.01)$ and $2.21 \pm 0.06$ $(P \leq 0.001)$; whereas the expression of SSTR $5 \mathrm{mRNA}$ increased by $1.47 \pm 0.05(P \leq 0.01)$ and $1.32 \pm$ $0.05(P \leq 0.05)$ in comparison to control group. No effect of exogenous injection BDNF on SSTR2 mRNA expression was observed (Figure 2C).

\section{GH concentration in the pituitary gland}

The mean concentration of $\mathrm{GH}$ hormone in pituitary in control, BDNF10 and BDNF60 animals was $111.35 \pm 3.25,139.83 \pm 1.59$ and
$140.28 \pm 2.84 \mu \mathrm{g} /$ pituitary, respectively. The $\mathrm{GH}$ concentrations were higher in both BDNF-treated groups in comparison to control group (Figure 3).



Figure 3. The concentration of growth hormone $(\mathrm{GH})$ in pituitary homogenate. Data are means \pm standard error of measurement; treatment groups: control group of animals which received Ringer-Locke infusion at dose of $480 \mu \mathrm{l}$ per day $(n=8)$, BDNF10 - group of animals which received brain-derived neurotrophic factor (BDNF) infusion at dose $10 \mu \mathrm{g} / 480 \mu \mathrm{l}(\mathrm{n}=8), \mathrm{BDNF60}$ - group of animals which received BDNF infusion at dose $60 \mu \mathrm{g} / 480 \mu \mathrm{l}(\mathrm{n}=8) ;{ }^{*}$ - indicates values significantly different at $P<0.05$ 
Table 2. Parameters of pulsatile growth hormone $(\mathrm{GH})$ release on day 0 and day 3: mean concentration, pulses frequency and pulse amplitude

\begin{tabular}{lllll}
\hline Parameters & $\begin{array}{l}\text { Day 0 } \\
\text { (all groups) }\end{array}$ & Day 3 & & \\
\cline { 2 - 5 } & control & BDNF 10 & BDNF 60 \\
\hline Mean concentration, $\mathrm{ng} / \mathrm{ml}$ & $4.62 \pm 0.08^{\mathrm{a}}$ & $4.80 \pm 0.11^{\mathrm{a}}$ & $6.39 \pm 0.40^{\mathrm{b}}$ & $6.42 \pm 0.16^{\mathrm{b}}$ \\
Pulse amplitude, $\mathrm{ng} / \mathrm{ml}$ & $2.52 \pm 0.22^{\mathrm{a}}$ & $2.18 \pm 0.26^{\mathrm{a}}$ & $4.80 \pm 0.60^{\mathrm{b}}$ & $4.05 \pm 0.62^{\mathrm{b}}$ \\
Pulse frequency, pulse/6h & $2.17 \pm 0.16$ & $2.41 \pm 0.27$ & $2.54 \pm 0.26$ & $3.06 \pm 0.23$ \\
\hline
\end{tabular}

Treatment groups: control - Ringer-Locke solution $480 \mu \mathrm{l} /$ day, BDNF10 - BDNF at a dose of $10 \mu \mathrm{g}$ per day, BDNF60 - BDNF at a dose of $60 \mu \mathrm{g}$ per day; values are presented as means \pm standard error of measurement; ${ }^{a b}-$ values with different superscripts in the same row are significantly different at $P<0.001$
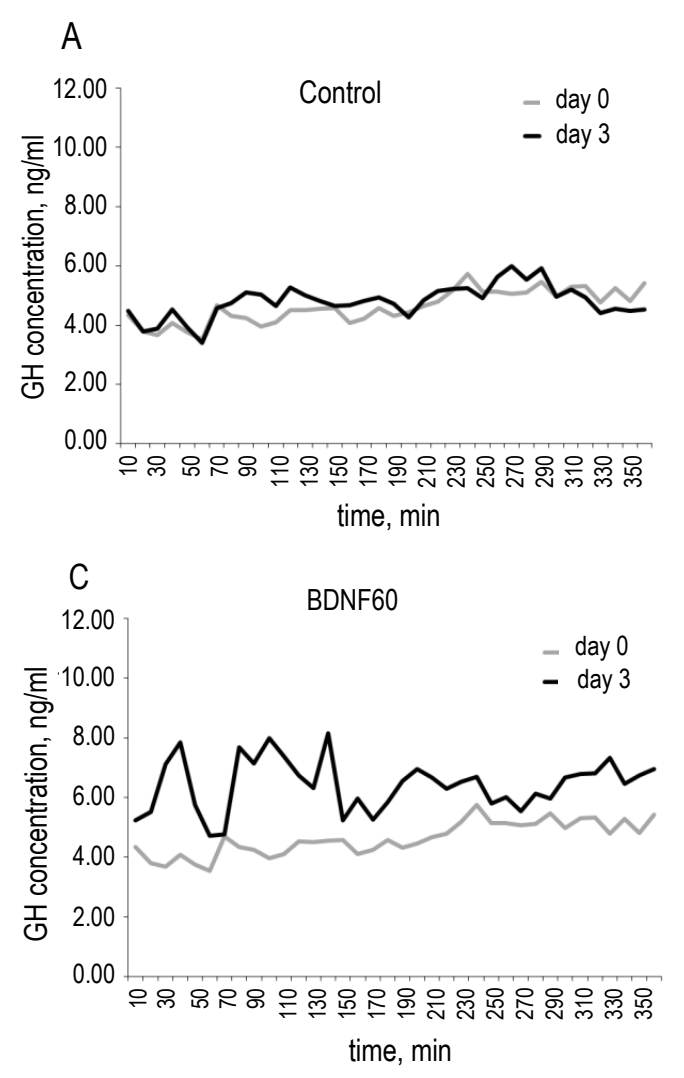

\section{GH plasma concentration and pulsatility pattern}

In all the experimental groups, similar mean GH plasma concentrations, pulse amplitudes and frequency patterns were observed on day 0 before starting the group-specific infusions (statistical analysis not presented). After the Ringer-Locke solution ICV injection, the GH-releasing parameters did not differ in the control animals between day 0 and day 3 . In contrast, at day 3 BDNF induced an increase $(P \leq 0.001)$ in the mean plasma $\mathrm{GH}$ concentration in the BDNF10 group $(6.39 \pm 0.40 \mathrm{ng} / \mathrm{ml})$ as well as the BDNF60 group $(6.42 \pm 0.16 \mathrm{ng} / \mathrm{ml})$ in comparison to mean value at day $0(4.62 \pm 0.08 \mathrm{ng} / \mathrm{ml})$. In addition, the GH pulse amplitude in both BDNF groups was significantly $(P \leq 0.001)$ elevated in comparison to control animals at day 3 as well as in comparison to basal value at day 0 . No significant changes in the pulse frequency parameters were

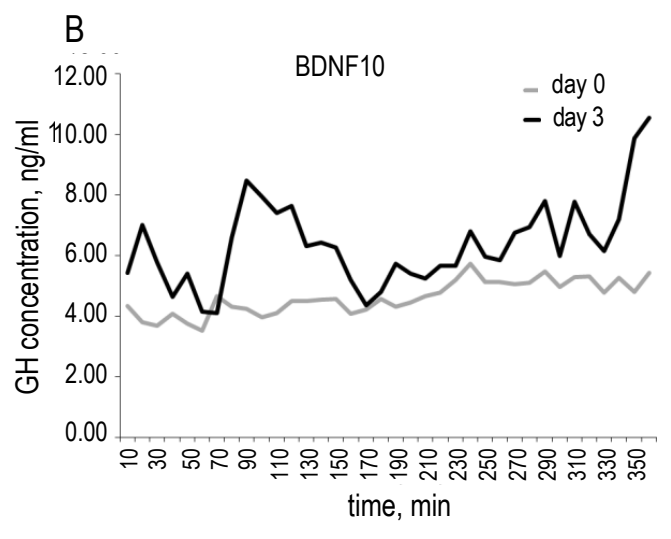

Figure 4. The pulsatile pattern of growth hormone $(\mathrm{GH})$ release in representative individual sheep on day 0 and day 3 of brain-derived neurotrophic factor (BDNF) infusion. Treatment groups: control group of animals which received Ringer-Locke infusion at dose of $480 \mu \mathrm{l}$ per day $(n=8)(A), B D N F 10$ - group of animals which received brainderived neurotrophic factor (BDNF) infusion at dose $10 \mu \mathrm{g} / 480 \mu \mathrm{l}$ $(n=8)(B), B D N F 60$ - group of animals which received BDNF infusion at dose $60 \mu \mathrm{g} / 480 \mu \mathrm{l}(\mathrm{n}=8)(\mathrm{C})$

observed in the experimental groups (Table 2). The changes in the pulsatile pattern of the $\mathrm{GH}$ release in the representative sheep from each group are presented in Figure 4.

\section{Discussion}

It was revealed that centrally infused BDNF affects somatotrophic axis activity in female sheep in the hypothalamus and pituitary. Exogenous BDNF induced a dose-dependent increase in GHRH mRNA expression in sheep MBH. Moreover, central BDNF administration increased the $G H$ mRNA expression in the pituitary as well as the GH pulse amplitude, which, consequently, increased the mean GH concentration in the blood plasma. The above observations suggest the up-regulation of the somatotrophic axis activity in female sheep after direct BDNF infusion into IIIv. 
Data on BDNF and its effects on somatotrophic axis function are still limited, and the available information does not fully reflect its physiological role in the mature organism. However, there are indications of a possible impact of BDNF on somatotrophic axis activity and a direct link between BDNF and hypothalamic neurons responsible for growth regulation. In a study performed on mice, it was shown that BDNF neurons are in strict coexistence with GHRH and SRIF neurons in the PVN nucleus, which is the main site of SRIF synthesis in the hypothalamus. Furthermore, double-fluorescence immunohistochemistry analyses showed that some BDNF neurons in the PVN nucleus can also express GHRH and SRIF hormones (An et al., 2015).

In our experimental model, there was a tendency to decrease the expression of SRIF mRNA in AHA in sheep treated with BDNF; however, the observed changes did not reach statistical significance. In contrast, the ICV-injected BDNF affected SRIF neuron activity in studies conducted on male rats. In situ hybridisation and RIA assays revealed that after BDNF treatment, the positive cells expressing SRIF mRNA in the PVN and SRIF hypothalamic content decreased (Givalois et al., 2006). The above information comes from studies performed on rodents - nocturnal, monogastric animals with different eating behaviour than ruminants. Therefore it should be noted that neurohormonal mechanisms regulating growth processes between rodents and ruminants are not the same and as a result the regulation of GH secretion is distinct. During malnutrition, the somatotrophic system in rodents is attenuated, which is revealed by a decrease in the secretory activity of GH-pituitary cells and GH concentration in the peripheral blood (Luque et al., 2008). On the contrary, in ruminants under similar conditions, an increase in the synthesis and release of GH is observed (Gładysz et al., 2001). Furthermore, the response of the somatotrophic axis on the peripheral hormones engaged in the appetite control is also opposite in ruminants and rodents. In ruminants, obestatin administration evoked up-regulation of the somatotrophic axis and as result, the augmentation of GH release was stated (Wójcik-Gładysz et al., 2018). Contrary, in rats, a decrease in the GH concentration as a result of the obestatin induced withdrawal of the ghrelin stimulating effect was observed (Zizzari et al., 2007; Hassouna et al., 2012). The results of other studies revealed that peripheral injections or infusions of obestatin to the central nervous system did not affect the GH levels (Sibilia et al., 2006; Nogueiras et al., 2007; Yamamoto et al.,
2007). Thus, the results obtained on sheep models could not be transformed directly on other species.

Our research also showed that central BDNF administration increased GHRH mRNA expression in the $\mathrm{MBH}$ area. As mentioned before, $B D N F$ and its receptor mRNA are expressed in the VMN, DMN and ARC nuclei, which are positioned in the $\mathrm{MBH}$ (Barde et al., 1982; Unger et al., 2007). This information constitutes a premise for a direct interaction between BDNF and GHRH neurons. However, to the best of our knowledge, there are no data on the existence of BDNF receptors on GHRH or SRIF neurons. To confirm this hypothesis, analyses, such as double-staining immunohistochemistry, need to be performed to ascertain the possible morphological connections.

It is also likely that BDNF can act in a non-direct manner via other neurotransmitters to affect GHRH expression in $\mathrm{MBH}$. Studies conducted on rodents (in vivo and in vitro models) have revealed that BDNF may affect NPY mRNA and protein expression, $P O M C$ (a precursor of $\alpha-\mathrm{MSH}$ ) and $A g R P$ mRNA and $\alpha$-MSH protein expression in the ARC nucleus, and receptor (MC4R) expression (Barnea and Roberts, 2001; Nicholson et al., 2007; Xapelli et al., 2008; Byerly et al., 2009; Takei et al., 2014; Yoshihara and Ogawa, 2021). Furthermore, the results of our previous study showed that central BDNF infusion induces changes in mRNA expression in the sub-populations of NPY/AgRP and CART/ $\alpha$ MSH neurons in sheep hypothalamus (Przybył et al., 2020). It was demonstrated that the central infusion of BDNF induced dose-dependent changes in NPY, AgRP, CART, POMC and peptidylglycine alpha-amidating monooxygenase (PAM - gene encoding an enzyme that converts POMC into $\alpha-\mathrm{MSH}$ ) mRNA expression in the ARC nucleus. It is also worth noting that BDNF may change the expression of selected miRNAs, which may be involved in the post-transcriptional regulation of NPY, CART and POMC mRNA expression (Unger et al., 2007; Przybył et al., 2020). Those suggest that BDNF as a neuromodulator may affect the hypothalamic neuronal network responsible for appetite regulation in the ARC nucleus of sheep, thereby modulating the somatotrophic axis activity. Moreover, as was previously mentioned, both GHRH and the appetite-regulating centre neurons are located in the $\mathrm{ARC}$, and other previous studies have reported that neuropeptides creating these appetite-regulating network can activate GHRH neurons in the ARC and inhibit SRIF cells, which in turn affects the release of GH. 
At the pituitary level, BDNF central administration seems to trigger alterations in mRNA expression in a specific way. In the present study, BDNF increased GHRHR, GH and SSTR5 mRNA expression, but it did not change SSTR 2 mRNA expression in the pituitary. Furthermore, after BDNF treatment, no changes in GH concentration in the pituitary cells were observed, but at the same time, an increase in GH concentration in the peripheral blood resulting from an increase in pulse amplitude was observed. This 'image' of hormone activity can be interpreted as the enhancement of GH synthesis in the pituitary somatotrophic cells and the simultaneous rapid release of GH into the blood. Therefore, our results indicate that BDNF may influence the secretory activity of $\mathrm{GH}$; however, the mechanism underlying these changes should be further investigated in the future.

\section{Conclusions}

It was shown that the central infusion of brainderived neurotrophic factor (BDNF) in sheep may stimulate the somatotrophic axis, as evidenced by the increase in the concentrations of growth hormone in the peripheral blood. It can be assumed that BDNF exerts its effect through the growth hormone releasing hormone (GHRH). Therefore, at the central nervous system level, BDNF may be another neuropeptide that can modulate the activity of the somatotrophic axis in female sheep. Considering the fact that changes in mRNA levels do not precisely reflect the respective cellular translational activity, the exact determination of the effect that BDNF exerts on the main components involved in the growth processes regulation in, e.g., hypothalamic GHRH neurons, hypothalamic somatostatin neurons and pituitary somatotrophic cells requires further studies.

\section{Acknowledgements}

The authors would like to thank veterinary surgeons K. Roszkowicz-Ostrowska and J. Rutkowski for the help in brain surgery, E. Skrzeczyńska, A. Misztal and K. Biernacka for the help in performing the experiments, and W. Mrozek and R. Druchniak for animal care. Presented study is the part of B.J. Przybył $\mathrm{PhD}$ dissertation.

\section{Funding}

This research was supported by the funds provided by the National Science Centre (Poland) PRELUDIUM 9 grant no. 2015/17/N/NZ9/01110.

\section{Conflict of interest}

The authors declared that there is no conflict of interest.

\section{References}

An J.J., Liao G.Y., Kinney C.E., Sahibzada N., Xu B., 2015. Discrete BDNF neurons in the paraventricular hypothalamus control feeding and energy expenditure. Cell Metab. 22, 175-188, https://doi.org/10.1016/j.cmet.2015.05.008

Barde Y.A., Edgar D., Thoenen H., 1982. Purification of a new neurotrophic factor from mammalian brain. EMBO J. 1, 549-553, https://doi.org/10.1002/j.1460-2075.1982.tb01207.x

Barnea A., Roberts J., 2001. Induction of functional and morphological expression of neuropeptide $Y$ (NPY) in cortical cultures by brain-derived neurotrophic factor (BDNF): evidence for a requirement for extracellular-regulated kinase (ERK)-dependent and ERK-independent mechanisms. Brain Res. 919, 57-69, https://doi.org/10.1016/S0006-8993(01)02999-7

Byerly M.S., Simon J., Lebihan-Duval E., Duclos M.J., Cogburn L.A., Porter T.E., 2009. Effects of BDNF, $T_{3}$, and corticosterone on expression of the hypothalamic obesity gene network in vivo and in vitro. Am. J. Physiol. Regul. Integr. Comp. Physiol. 296, R1180-R1189, https://doi.org/10.1152/ajpregu.90813.2008

Cordeira J.W., Frank L., Sena-Esteves M., Pothos E.N., Rios M., 2010. Brain-derived neurotrophic factor regulates hedonic feeding by acting on the mesolimbic dopamine system. J. Neurosci. 30, 2533-2541, https://doi.org/10.1523/JNEUROSCI.5768-09.2010

Givalois L., Naert G., Tapia-Arancibia L., Arancibia S., 2006. Involvement of brain-derived neurotrophic factor in the regulation of hypothalamic somatostatin in vivo. J. Endocrinol. 188, 425-433, https://doi.org/10.1677/joe.1.06578

Gładysz A., Krejči P., Šimůnek J., Polkowska J., 2001. Effects of central infusions of neuropeptide $Y$ on the somatotropic axis in sheep fed on two levels of protein. Acta Neurobiol. Exp. (Wars.) 61, 255-266

Goodman R.L., Karsch F.J., 1980. Pulsatile secretion of luteinizing hormone: differential suppression by ovarian steroids. Endocrinology 107, 1286-1290, https://doi.org/10.1210/endo-107-5-1286

Hassouna R., Zizzari P., Viltart O., Yang S.K., Gardette R., Videau C., Badoer E., Epelbaum J., Tolle V., 2012. A natural variant of obestatin, Q90L, inhibits ghrelin's action on food intake and $\mathrm{GH}$ secretion and targets NPY and GHRH neurons in mice. PLOS ONE 7, e51135, https://doi.org/10.1371/journal. pone.0051135

Herman A.P., Wojtulewicz K., Bochenek J., Krawczyńska A., Antushevich H., Pawlina B., Zielińska-Górska M., Herman A., Romanowicz K., Tomaszewska-Zaremba D., 2017. Endotoxin-induced inflammation disturbs melatonin secretion in ewe. Asian-Australas. J. Anim. Sci. 30, 1784-1795, https:// doi.org/10.5713/ajas.17.0196

Kennedy D., 2012. Sheep Reproduction Basics and Conception Rates. Ministry of Agriculture, Food and Rural Affairs. Guelph, Ontario (Canada), http://www.omafra.gov.on.ca/english/livestock/sheep/facts/12-037.htm

Krawczyńska A., Antushevich H., Bochenek J., Wojtulewicz K., Pawlina B., Herman A.P., Zięba D.A., 2019. Photoperiodic conditions as a factor modulating leptin influence on proinflammatory cytokines and their receptors gene expression in ewe's aorta. J. Anim. Feed Sci. 28, 128-137, https://doi. org/10.22358/jafs/110022/2019 
Liu Y., Wang C., Guo G., Huo W., Zhang Y., Pei C., Liu Q., Zhang S., 2019. Growth performance of post-weaned Holstein male calves accelerated by branched-chain volatile fatty acids addition with up-regulated hepatic $M T O R$ expression via insulin and insulin-like growth factor-1 (IGF-1) signalling pathway. J. Anim. Feed Sci. 28, 244-253, https://doi.org/10.22358/ jafs/112319/2019

Luque R.M., Park S., Kineman R.D., 2008. Role of endogenous somatostatin in regulating $\mathrm{GH}$ output under basal conditions and in response to metabolic extremes. Mol. Cell Endocrinol. 286, 155-168, https://doi.org/10.1016/j.mce.2007.12.005

Marmigère F., Rage F., Tapia-Arancibia L., 2001. Regulation of brainderived neurotrophic factor transcripts by neuronal activation in rat hypothalamic neurons. J. Neurosci. Res. 66, 377-389, https://doi.org/10.1002/jnr.1230

Nawa H., Pelleymounter M., Carnahan J., 1994. Intraventricular administration of BDNF increases neuropeptide expression in newborn rat brain. J. Neurosci. 14, 3751-3765, https://doi. org/10.1523/JNEUROSCI.14-06-03751.1994

Nicholson J.R., Peter J.C., Lecourt A.C., Barde Y.A., Hofbauer K.G., 2007. Melanocortin-4 receptor activation stimulates hypothalamic brain-derived neurotrophic factor release to regulate food intake, body temperature and cardiovascular function. J. Neuroendocrinol. 19, 974-982, https://doi. org/10.1111/j.1365-2826.2007.01610.x

Nogueiras R., Pfluger P., Tovar S. et al., 2007. Effects of obestatin on energy balance and growth hormone secretion in rodents. Endocrinology 148, 21-26, https://doi.org/10.1210/en.20060915

Patapoutian A., Reichardt L.F., 2001. Trk receptors: mediators of neurotrophin action. Curr. Opin. Neurobiol. 11, 272-280, https://doi.org/10.1016/S0959-4388(00)00208-7

Peiris T.S., Machaalani R., Waters K.A., 2004. Brain-derived neurotrophic factor mRNA and protein in the piglet brainstem and effects of Intermittent Hypercapnic Hypoxia. Brain Res. 1029, 11-23, https://doi.org/10.1016/j.brainres.2004.09.024

Pfaffl M.W., Horgan G.W., Dempfle L., 2002. Relative expression software tool $\left(\mathrm{REST}^{\circ}\right)$ for group-wise comparison and statistical analysis of relative expression results in real-time PCR. Nucleic Acids Res. 30, e36, https://doi.org/10.1093/ nar/30.9.e36

PfafflM.W., TichopadA.,PrgometC., Neuvians T.P., 2004. Determination of stable housekeeping genes, differentially regulated target genes and sample integrity: BestKeeper - Excel-based tool using pair-wise correlations. Biotechnol. Lett. 26, 509-515, https://doi.org/10.1023/b:bile.0000019559.84305.47

Polkowska J., Wańkowska M., 2010. Effects of maternal deprivation on the somatotrophic axis and neuropeptide $Y$ in the hypothalamus and pituitary in female lambs. The histomorphometric study. Folia Histochem. Cytobiol. 48, 299-305, https://doi.org/10.2478/v10042-010-0024-0

Polkowska J., Wójcik-Gładysz A., Wańkowska M., Bruneau G., Tillet Y., 2008. Prepubertal changes in the synthesis, storage and release of the somatostatin in the hypothalamus of female lambs: A morphofunctional study. J. Chem. Neuroanat. 36, 53-58 https://doi.org/10.1016/j.jchemneu.2008.05.007

Przybył B.J., Szlis M., Wójcik-Gładysz A., 2020. Brain-derived neurotrophic factor affects mRNA and miRNA expression of the appetite regulating centre in the sheep arcuate nucleus. Ann. Anim. Sci. 20, 853-869, https://doi.org/10.2478/aoas2020-0015

Przybył B.J., Szlis M., Wójcik-Gładysz A., 2021. Brain-derived neurotrophic factor (BDNF) affects the activity of the gonadotrophic axis in sheep. Horm. Behav. 131, 104980, https://doi.org/10.1016/j.yhbeh.2021.104980
Rekešiutė A., Januškauskas A., Kerzienė S., Sutkevieienė N., Vaieiùlienè G., Rutkauskas A., Žilinskas H., 2020. Evaluation of efficacy of selected estrous synchronization programs depending on the functional state of the ovaries, heifers and cows of meat breed. J. Anim. Feed Sci. 29, 175-179, https:// doi.org/10.22358/jafs/124048/2020

Sibilia V., Brescian E., Lattuada N., Rapetti D., Locatelli V., De Luca V., Donà C., Netti A., Torsello F., Guidobono F., 2006. Intracerebroventricular acute and chronic administration of obestatin minimally affect food intake but not weight gain in the rat. J. Endocrinol. Invest. 29, RC31-RC34, https://doi. org/10.1007/BF03349204

Slaba J., Krejcí P., Skarda J., Huybrechts L.M., Decuypere E., Herrmann H., 1994. Plasma profiles of somatotropin and IGF-I in diary cows following application of two preparations of recombinant bovine somatotropin in a sustained release vehicle. Physiol. Res. 43, 37-43

Strzetelski J.A., Brzóska F., Kowalski Z.M., Osięgłowski S., 2014. Feeding Recommendation for Ruminants and Feed Tables (in Polish: Zalecenia Żywieniowe dla Przeżuwaczy i Tabele wartości pokarmowej pasz). National Research Institute of Animal Production. Krakow (Poland)

Szlis M., Polkowska J., Skrzeczyńska E., Przybył B.J., Wójcik-Gładysz A., 2018. Does obestatin modulate the hypothalamic appetiteregulating network in peripubertal sheep? J. Anim. Physiol. Anim. Nutr. 102, 690-700, https://doi.org/10.1111/jpn.12879

Szlis M., Wójcik-Gładysz A., Przybył B.J., 2020. Central obestatin administration affect the $\mathrm{LH}$ and FSH secretory activity in peripubertal sheep. Theriogenology 145, 10-17, https://doi.org/10.1016/j. theriogenology.2020.01.032

Takei N., Furukawa K., Hanyu O., Sone H., Nawa H., 2014. A possible link between BDNF and mTOR in control of food intake. Front. Psychol. 5, 1093, https://doi.org/10.3389/fpsyg.2014.01093

Tillet Y., Picard S., Bruneau G., Ciofi P., Wańkowska M., Wójcik-Gładysz A., Polkowska J., 2010. Hypothalamic arcuate neuropeptide Y-neurons decrease periventricular somatostatin-neuronal activity before puberty in the female lamb: Morphological arguments. J. Chem. Neuroanat. 40, 265-271 https://doi.org/10.1016/j.jchemneu.2010.07.003

Timmusk T., Palm K., Metsis M., Reintam T., Paalme V., Saarma M., Persson H., 1993. Multiple promoters direct tissue-specific expression of the rat BDNF gene. Neuron 10, 475-489, https://doi.org/10.1016/0896-6273(93)90335-0

Traczyk W., Przekop F., 1963. Methods of investigation of the function of the hypothalamus and hypophysis in chronic experiments in sheep (in Polish). Acta. Physiol. Pol. 14, 217-226

Unger T.J., Calderon G.A., Bradley L.C., Sena-Esteves M., Rios M., 2007. Selective deletion of $B d n f$ in the ventromedial and dorsomedial hypothalamus of adult mice results in hyperphagic behavior and obesity. J. Neurosci. 27, 14265-14274, https:// doi.org/10.1523/JNEUROSCI.3308-07.2007

Welento J., Szteyn S., Milart Z., 1969. Observations on the stereotaxic configuration of the hypothalamus nuclei in the sheep. Anat. Anz. 124, 1-27

Wójcik-Gładysz A., Szlis M., 2016. Hypothalamo-gastrointestinal axis - role in food intake regulation. J. Anim. Feed Sci. 25, 97-108, https://doi.org/10.22358/jafs/65569/2016

Wójcik-Gładysz A., Szlis M., Misztal A., Przybył B.J., Polkowska J., 2018. Obestatin stimulates the somatotrophic axis activity in sheep. Brain Res. 1678, 278-287, https://doi.org/10.1016/j. brainres.2017.10.036

Wójcik-Gładysz A., Szlis M., Przybył B.J., Polkowska J., 2019. Obestatin may affect the GnRH/KNDy gene network in sheep hypothalamus. Res. Vet. Sci. 123, 51-58, https://doi. org/10.1016/j.rvsc.2018.12.010 
Wójcik-Gładysz A., Wańkowska M., Gajewska A., Misztal T., Szlis M., Polkowska J., 2014. The effect of intracerebroventricular infusions of ghrelin on the secretory activity of the $\mathrm{GnRH} / \mathrm{LH}$ system in peripubertal ewes. J. Anim. Feed Sci. 23, 299-308, https://doi.org/10.22358/jafs/65665/2014

Wójcik-Gładysz A., Wańkowska M., Gajewska A., Misztal T., Zielińska-Górska M., Szlis M., Polkowska J., 2016. Effects of intracerebroventricular infusions of ghrelin on secretion of follicle-stimulating hormone in peripubertal female sheep. Reprod. Fertil. Dev. 28, 2065-2074, https://doi.org/10.1071/ RD16028

Wójcik-Gładysz A., Wańkowska M., Misztal T., Szczepankiewicz D., Romanowicz K., Polkowska J., 2010. The effect of intracerebroventricular infusion of leptin on the secretory activity of the somtotropic axis in fasted prepubertal lambs. J. Anim. Feed Sci. 19, 379-397, https://doi.org/10.22358/ jafs/66301/2010
Xapelli S., Bernardino L., Ferreira R. et al., 2008. Interaction between neuropeptide Y (NPY) and brain-derived neurotrophic factor in NPY-mediated neuroprotection against excitotoxicity: a role for microglia. Eur. J. Neurosci. 27, 2089-2102, https:// doi.org/10.1111/j.1460-9568.2008.06172.x

Yamamoto D., Ikeshita N., Daito R. et al., 2007. Neither intravenous nor intracerebroventricular administration of obestatin affects the secretion of GH, PRL, TSH and ACTH in rats. Regul. Pept. 138, 141-144, https://doi.org/10.1016/j.regpep.2006.09.001

Yoshihara Y., Ogawa Y., 2021. Handling stress-induced rumianal microbiota changes reduce grass hay degradability in sheep. J. Anim. Feed Sci. 30, 159-164, https://doi.org/10.22358/ jafs/135543/2021

Zizzari P., Longchamps R., Epelbaum J., Bluet-Pajot M.T., 2007. Obestatin partially affects ghrelin stimulation of food intake and growth hormone secretion in rodents. Endocrinology 148, 1648-1653, https://doi.org/10.1210/en.2006-1231 